\title{
CHD2 Geninde Denovo Heterozigot Yeni Bir Mutasyonun Saptandığı Bir Epileptik Ensefalopati Olgusu
}

\section{A Case of Epileptic Encephalopathy with a New Denovo Heterozygous Mutation in the CHD2 Gene}

\author{
Çisil Çerçi Kubur ${ }^{1 *}$, Aslı Kübra Atasever ${ }^{1}$, Celil Yılmaz ${ }^{1}$, Sibğatullah Ali Orak ${ }^{1}$, Muzaffer Polat ${ }^{1}$ \\ ${ }^{1}$ Manisa Celal Bayar Üniversitesi Tıp Fakültesi Çocuk Nöroloji Anabilim Dalı, Manisa, Türkiye. \\ e-mail: cisilcerci@gmail.com, akubrat@gmail.com, cllyilmaz@yahoo.com,maviihsan@gmail.com, \\ polatmuzaffer@yahoo.com. \\ ORCID: 0000-0002-1822-3777 \\ ORCID: 0000-0003-2608-0443 \\ ORCID: 0000-0002-0951-8258 \\ ORCID: 0000-0002-1955-5431 \\ ORCID: 0000-0002-1291-6417 \\ *Sorumlu yazar/ Corresponding Author: Çisil Çerçi Kubur \\ Gönderim Tarihi / Received: 23.09.2021 \\ Kabul Tarihi / Accepted: 13.10.2021 \\ DOI: $10.34087 /$ cbusbed.999892
}

\begin{abstract}
$\ddot{\mathbf{O z}}$
Epileptik ensefalopatiler (EE), çoklu nöbet tipleri, gelişimsel gecikme ve hatta gerileme ile karakterize ciddi epilepsi sendromlarıdır. CHD2'deki (kromodomain sarmal DNA bağlayıcı protein 2) patojenik varyantlar, epileptik ensefalopatilerde ve ayrıca zihinsel engellilikten atonik-miyoklonik epilepsiye kadar değişen fenotipik değişkenlik spektrumuna sahip nörogelişimsel bozukluklarda bildirilmiştir. Biz bu olgu sunumunda oğul, erkek kardeş ve anneden oluşan kalıtsal bir patojenik $C H D 2$ varyantı ailesini rapor ediyoruz. Bu vaka, aile içinde aynı $C H D 2$ mutasyonu ile oluşan fenotipik heterojeniteyi gösterir ve $C H D 2$ ile ilişkili nörogelişimsel bozuklukların potansiyel kalıtsallığını doğrular.
\end{abstract}

Anahtar kelimeler: CHD2, Epileptik ensefalopati, Nörogelişimsel bozukluklar

Abstract

Epileptic encephalopathies (EE) are severe epilepsy syndromes characterized by multiple seizure types, developmental delay and even regression. Pathogenic variants in CHD2 (chromodomain helicase DNA-binding protein 2) have been reported in epileptic encephalopathies and also neurodevelopmental disorders with spectrum of phenotypic variability, ranging from intellectual disability to atonic-myoclonic epilepsy. Here, we report a family of an inherited pathogenic CHD2 variant in affected son, brother and mother. This case demonstrates intrafamilial phenotypic heterogeneity and confirms potential heritability of CHD2-related neurodevelopmental disorders.

Key words: $C H D 2$, Epileptic encephalopathy, Neurodevelopmental disorder

\begin{abstract}
1. Giriş
Epileptik ensefalopatiler (EE), genellikle erken yaşta ortaya çıkan, tedaviye dirençli nöbetler, EEG'de epileptik deşarjlar, ilerleyici bilişsel, davranışsal ve nörolojik kusurlarla giden ve bazen de erken ölüme yol açan bir grup hastalıktır. EE'in genetik etiyolojisinin belirlenmesi ve moleküler altyapısı hakkında yapılan araştırmalar giderek artmaktadır. Epileptik ensefalopatili hastalarda yapilan bir çalışmada CHD2 geninin \%1,2 oranı ile SCN1A,
\end{abstract}

CDKL5 ve STXBP1'den sonra mutasyonlarının hastalığa sebep olduğu en sık dördüncü gen olduğu belirlenmiştir [1].

CHD2 ile ilişkili myoklonik ensefalopatiler; tekrarlayan dirençli nöbetler, fotosensitivite, bilişsel, davranışsal ve motor işlevlerde ilerleyici bozulmayla karakterize epileptik bir sendromdur. Nöbetler çocukluk çağında yaşamın ikinci yılında başlar. Her hastada farklı nöbet tipleri görülebilir. S1klıkla myoklonik nöbetler gözlenirken atonik, absans, tonik- 
klonik gibi farklı tür nöbetler de görülebilir [2]. Nöbetler refrakter karakterde olup çoğunlukla antiepileptiklere dirençlidir. İzlemde hastalarda status epileptikus gözlenebilmektedir [3].

$C H D 2$ 'deki heterozigot patojenik varyantları, erken başlangıçlı refrakter epileptik ensefalopati, gelişimsel gecikme, zihinsel engellilik ve otizm spektrum bozukluğu ile giden nörogelişimsel bir grup hastalığa yol açar. CHD2'nin kromatinin yeniden şekillenmesinde rol oynadığı ve insan beyninde geniş çapta ifade edildiği bilinmesine rağmen, spesifik işlevi bilinmemektedir. Benzer şekilde, aynı varyantı barındıran hastaların değişken fenotipler gösterebildiği görülürken, literatürde bildirilen olguların büyük kısmında CHD2 geninde belirlenen hastalık yapıcı varyantın de novo olduğu gözlenmektedir. Bu durum, nadir rastlanan bu durumun sebep olduğu fenotipin, aile içi değişkenliğinin araștırılmasını güçleştirmektedir. $[4,5,6]$.

CHD2 genindeki mutasyonlar sonucu olduğu bildirilen klinik fenotiplere sahip literatürdeki olgular araştırıldığında, bugüne kadar sadece 2 makalede aile içi geçiş bildirildiği görülmüştür. $\mathrm{Bu}$ araştırmalardan birinde iki kardeşte, diğerinde ise anne ve kızında klinik fenotip ve patojenik heterozigot mutasyon bildirilmiştir.

$\mathrm{Bu}$ olgu sunumunda tipik klinik bulguları bulunan CHD2 geninde ayn1 heterozigot mutasyonun saptandığı 2 kardeş ve aynı mutasyon belirlenmiş olduğu anneleri sunularak, literatürdeki kalıtsal mutasyona sahip 3. Aileyi bildirmeyi amaçladık.

\section{Olgu}

On üç yaşında erkek hasta sorunsuz bir gebeliği izleyerek normal vajinal yolla komplikasyonsuz olarak doğmuştu. Baştan itibaren gelişim basamakları geriydi ve kazanımları yoktu. Nöbetler 5 yaşında başlamış, nöbet tipleri göz kapağı miyoklonisi, jeneralize tonik ve atonik şeklideydi. Fizik muayenesinde mikrosefalisi $(<3 \mathrm{p})$ olup dismorfik bulgusu yoktu. Bilateral derin tendon refleksleri artmıştı, bilateral klonus alınmaktaydı. Spastik tetraparezi ve ağır psikomotor gerilik mevcuttu. Skolyoz ve eklem kontraktürleri nedeniyle yatağa bağımlıydı..

Anne ve baba ikinci derece kuzen evliliğiydi ve sağlıklıydı. Ailede dokuz yaşındaki kardește de 4 yaşında başlayan dirençli nöbetler, spastik tetrapareji ve ağır psikomotor retardasyon mevcuttu. Diğer dört kardeş sağlıklıydı.

Kranial manyetik rezonans görüntülemesinde ekstraaksiyel mesafede giruslarda 1 lımlı belirginlik ve posterior fossada belirgin parankimal atrofi saptandi. Bakılan metabolik testlerinden LA, PA, amonyak, idrar aminoasit kromotografisi, organik asitler ve TANDEM-MS de patoloji saptanmadi. Elektroensefalografide multifokal keskin, diken,keskin karakterde yavaş dalga paroksizmleri gözlendi. $\mathrm{Na}$ valproat, levetirecetam ve lakozamid tedavilerine rağmen nöbet kontrolü tam sağlanamadı. Dirençli nöbetler, elektroensefalografi (EEG) bulguları ve psikomotor gelişimde gerilik ile gelen, dokuz yaşında kardeşinde de benzer öykü bulunan hastadan epileptik ensefalopati ön tanısı ile TruSight Exome Yeni Nesil Dizi Analizi paneli çalışıldı. Bu panelde öncelikli olarak bilinen epileptik ensefalopati genleri açısından yapılan değerlendirme sonrasında CHD2 geninde heterozigot c.214G>T (p.Gly72Cys) varyantı belirlendi. $\mathrm{Bu}$ varyant daha önce veri tabanlarında rs1034945378 numaras1 ile bildirilirken, bu varyantın klinik fenotipi ile ilgili verileri içeren bir araştırma ya da olgu daha önce tanımlanmamıştı. ACMG 2015 kriterlerine göre "etkinliği bilinmeyen varyant (VUS)" olarak siniflandirıldı. Olgunun aile segregasyonunda etkilenmiş erkek kardeşinde ve KENT-EGY zeka testiyle yapilan taramada hafif düzeyde zeka geriliği olan annesinde aynı varyant tespit edilirken, olgunun babası bu varyant açısından normaldi.

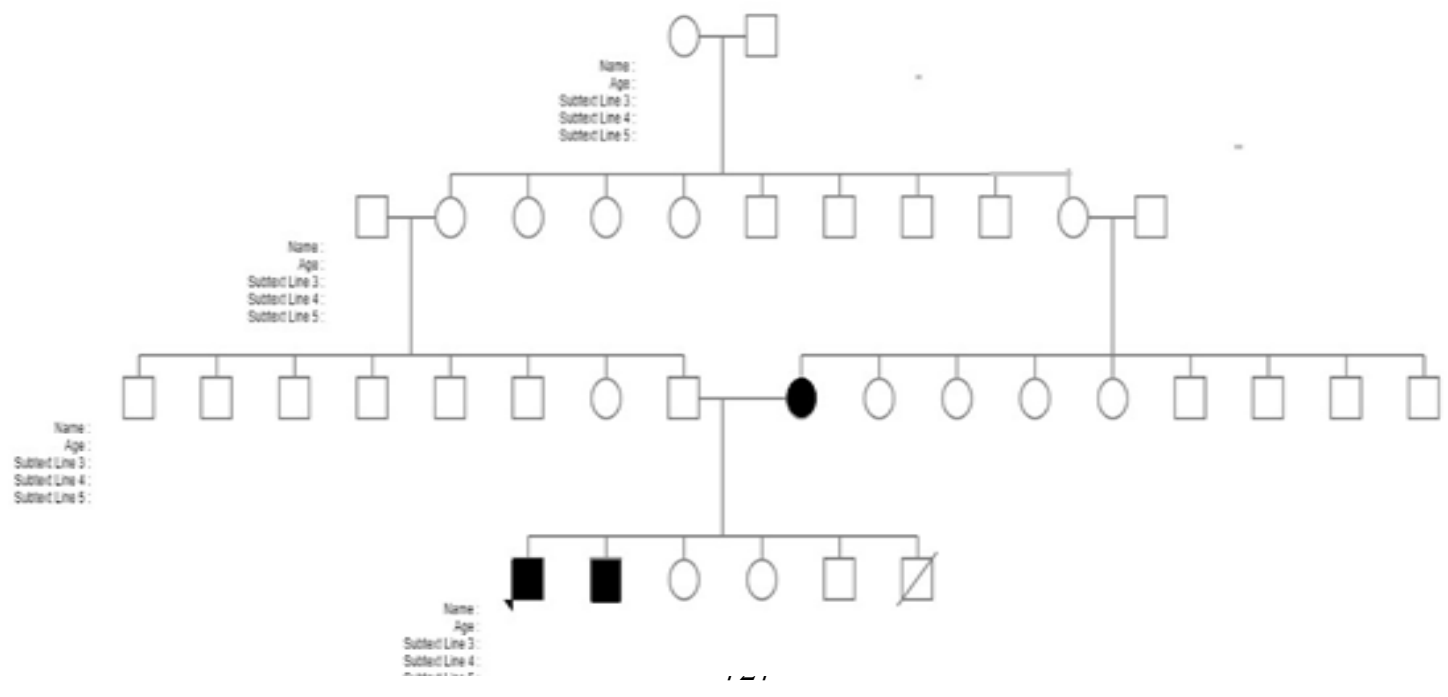


Literatürde de benzer şekilde tanımlı vakalarda segregasyon analizi, tanımlanmamış varyantların fonksiyonel sonuçlarını tahmin etmek için de farklı birkaç yöntem kullanılmıştı ( Sanger dizilimi veya ikinci bir bağımsız moleküler inversiyon probu yakalama modeli) .

Yazılı onamı bu çalışmaya katılan hastanın ebeveynlerinden alınmıştır.

\section{Tartışma}

Kromodomain helikaz DNA bağlayıcı (CHD) protein ailesi, kromatin yapısının yeniden düzenlenmesine ve gen ekspresyonunu düzenlemek için gerekli histon varyantlarının birikmesine katkıda bulunan ATP'ye bağlı kromatin yeniden modelleyicilerdir. CHD1, CHD2, CHD4, CHD7 ve CHD8'deki patojenik varyantlar, otizm spektrum bozukluğu, nörokognitif gerilik ve epilepsi dahil olmak üzere bir dizi nörolojik fenotip ile ilişkilendirildiğinden, CHD proteinlerinin, nörogelişimde önemli bir rol oynadığ sürülmüştür. $\quad C H D 2$ 'deki patojenik varyantlar, insanlarda gelişimsel epileptik ensefalopati ile ilişkilendirilmiştir. Ancak bu varyantların bu bozukluğa nasıl katkıda bulunduğu hakkında çok az veri bilinmektedir. Dokuz CHD aile üyesi arasında, CHD2'nin insan beyni üzerine; proliferasyon, nörogenez, nöronal farklılaşma, kromatin yeniden modellemesi ve DNA onarımındaki rolü gibi gelişimsel ve işlevsel olarak benzersiz bir rolü vardır [4].

CHD2'nin kromatinin yeniden şekillenmesinde rol oynadığ 1 ve insan beyninde geniş çapta ifade edildiğ bilinmesine rağmen, spesifik işlevi bilinmemektedir. Açık bir genotip-fenotip korelasyonu yoktur. CHD2 gen mutasyonu bir hastada izole otizme yol açarken aynı varyantı paylaşan başka bir hastada zihinsel engellilik ve epilepsiye yol açabilir $[5,7]$.

CHD2 gen mutasyonu sonucu ortaya çıkan klinik fenotiplerin kalitım paterni otozomal dominant kalıtıma uymaktadır. Bugüne kadar, CHD2 ile ilişkili nörogelişimsel bozukluklara yol açan patojenik varyantların genellikle de novo oluştuğu bildirilmiştir [5,8]. Literatürde CHD2 mutasyonlarına bağlı klinik bulguların bildirildiği 50'den az araştırma bulunmaktadır. Bunların 10'dan azı epileptik ensefalopati ile ilişkilidir. $\mathrm{Bu}$ bulgu, bu gendeki mutasyonlar sonucu eksik penetrans ve değişken ekspresivite gibi kavramları düşündürmektedir.

$\mathrm{Bu}$ olgu sunumunda, perinatal ve postnatal öyküde özellik olmayan, yaklaşık 5 yaşında başlayan, özellikle uyarı ile ortaya çıkan ilerleyici karakterdeki myoklonik nöbetleri ve global gelişim geriliği bulunan, CHD2 geninde heterozigot bir varyant saptanan bir olgu ve benzer bulgulara sahip kardeşi sunulmaktadır. $\mathrm{Bu}$ ailede iki kardeşte saptanan varyantın, olguların klinik bulgusu olmayan annelerinden kalıtıldığ 1 belirlenmiştir. Ailedeki bu varyantın klinik fenotip ile ilişkisi açısından, özellikle anne yeniden KENT-EGY testi ile değerlendirilerek, hafif düzey intellektüel yetersizlik saptanmıştır.
Literatürde çoğunlukla de novo mutasyonlar sonucu olarak ortaya çıktığı bildirilen bu durumun, daha önce 2 kez kalıtsal olarak aynı aile içinde tekrarladı $\breve{g}_{1}$ bildirilmiş olup, bizim olgularımız literatürdeki üçüncü ailedir. Lebrun ve arkadaşları, gelişimsel gerilik ve epileptik ensefalopati tablosundaki iki kardeşte CHD2 geninde heterozigot c.1934C $>$ T (p.Thr645Met) varyantını saptarken, olguların her iki ebeveyninin ve sağlıklı kızkardeşlerinin bu varyantı taşımadığı görülmüştür. Araştırmacılar, ileri inceleme yapmasa da bu durumu gonadal hücre mozaisizme bağlamışlardır [9]. Petersen ve arkadaşları, mikrosefali, gelişme geriliği ve epileptik ensefalopatisi bulunan k1z olguda CHD2 geninde heterozigot c.628G $>\mathrm{T}$ (p.Glu210Ter) saptarlarken, aynı varyantı olgunun 33 yaşındaki annesinde de saptadıklarını bildirmişlerdir. $\mathrm{Bu}$ araştırmada, ağır klinik fenotipe sahip k1z olguya rağmen, aynı mutasyona sahip annesinin çocukken monoterapi ile kolayca kontrol edilebilen epilepsisinin uzun yillardır tekrar etmediği, gelişiminin yaşının normallerine uygun olduğu tanımlanmaktadır [10]. Bizim olgularımı, CHD2 genindeki kalıtsal mutasyonlar sonucu oluşan klinik bulguların bildirildiği literatürdeki üçüncü çalışma olmaktadır.

Burada sunulan ailede tespit edilen c.214G>T (p.Gly72Cys) varyantı bir missens varyant olup, daha önce veri tabanlarında çok nadir saptansa da, klinik ile ilişkisi bildirilmemiştir. Minör allel frekansı gnomAD (Exome) veri tabanında \%0.0004 olarak 251420 allelde sadece $1 \mathrm{kez}$ bildirilirken, diğer hiçbir veri tabanında rastlanmamıştır. In silico protein modelleme programları ile yapilan patojenisite değerlendirmesinde SIFT, MutationTaster, FATHMM ve DANN programları bu varyantı patojenik olarak skorlamaktadır. Ayrıca varyantın genomda yüksek korunmuşluk gösteren bir noktada bulunması da (GERP skoru 4.82), patojeniteyi desteklemekteydi. Genetik epilepsi kavramı, bilinen veya varsayılan bir genetik bozukluğun doğrudan sonucu olarak nöbet bozukluğunun temel nedeni olmasıdır. Genetik çalışmaların katkısı ile ilgili bilgi, iyi çoğaltılmış ve hatta teşhis testlerinin temeli haline gelen spesifik moleküler genetik çalışmalardan elde edilebilir. Alternatif olarak, bir genetik bileşenin temel rolü, uygun şekilde tasarlanmış aile araştırmalarından elde edilen kanitlara dayanabilir.

Sonuç olarak, bu olgu sunumunda, CHD2 geninde kalıtsal bir varyant sonucu oluşan epileptik ensefalopati tablosundaki iki kardeş ve hafif düzey zeka geriliği olan anneleri bildirilmektedir. Kalıtsallığın gösterildiği literatüre sunulan bu üçüncü aile, bu gendeki varyantların aynı aile içinde farklı klinik heterojenitesini göstermekte ve bu sayede tablonun genotip-fenotip ilişkisinin öğrenilmesine katkı sağlamaktadır.

\section{Referanslar}

1.Carvill, G.L, Heavin, S.B, Yendle, S.C, et al., Targeted resequencing in epileptic encephalopathies identifies de novo 
mutations in CHD2 and SYNGAP1, Nature Genetics, 201, 45, $825-830$.

2. Guerrini, R, Mari, F, Dravet, C, Idiopathic myoclonic epilepsies in infancy and early childhood. In: Beureau M, Genton P, Dravet $\mathrm{C}$, et al., editors, Epileptic Syndromes in Infancy, Childhood and Adolescence, 5th ed., Montrouge, France, John Libbey, 2012,166.

3. Elizabeth, C, Galizia et al., CHD2 variants are a risk factor for photosensitivity in epilepsy, Brain, 2015,138, 1198-207.

4. Kay-Marie, J, Lamar, et al. ,Chromatin Remodeling Proteins in Epilepsy: Lessons From CHD2-Associated Epilepsy, Frontiers in molecular neuroscience, 2018, 11, 208.

5.Carvill, G, Helbig, I, Mefford, H, CHD2-related neurodevelopmental disorders, In R. A. Pagon, M. P. Adam, \& H. H. Ardinger (Eds.), GeneReviews ${ }^{\circledR}$ [Internet], Seattle, WA: University of Washington, 2015, 1993-2021.

6. Chénier, S, Yoon, G, Argiropoulos, B, Lauzon, J, Laframboise, R, Ahn, J.W, et al., CHD2 haploinsufficiency is associated with developmental delay, intellectual disability, epilepsy and neurobehavioural problems, Journal of Neurodevelopmental Disorders, 2014, 6, 9.

7.O'Roak, B.J, Stessman, H.A, Boyle, E.A, Witherspoon, K.T Martin, B, Lee, C, et al., Recurrent de novo mutations implicate novel genes underlying simplex autism risk, Nature communications, 2014, 5, 5595.

8. Suls A, Jaehn JA, Kecskes A, Weber Y, Weckhuysen S, Craiu DC, et al., De novo loss-offunction mutations in CHD2 cause a fever-sensitive myoclonic epileptic encephalopathy sharing features with Dravet syndrome, American journal of human genetics, 2013, 93, 967-75.

9. Lebrun, N, Parent, P, Gendras, J, Billuart, P, Poirier, K, Bienvenu, T, Autism spectrum disorder recurrence, resulting of germline mosaicism for a CHD2 gene missense variant, Clinical Genetics, 2017, 92, 669-70.

10. Petersen, A.K, Streff, H, Tokita, M, Bostwick, B.L, The first reported case of an inherited pathogenic CHD2 variant in a clinically affected mother and daughter, American journal of medical genetics, 2018, 176, 1667-9.

http://edergi.cbu.edu.tr/ojs/index.php/cbusbed isimli yazarın CBU-SBED başlıklı eseri bu Creative Commons Alıntı-Gayriticari4.0 Uluslararası Lisansı ile lisanslanmıştır. 